\title{
Kristen dan Teknologi: Etika, Literasi dan Ciptaan
}

\author{
Andreas Maurenis Putra
}

\begin{abstract}
Abstrak
Dengan kesadaran beretika, kemampuan literasi, dan kesadaran sebagai makhluk ciptaan Tuhan yang cerdas maka umat Kristiani dalam berbagai dinamika hidup mesti tetap memperlihatkan sebuah etika dan spiritualitas manusia, terutama dalam konteks etika dan spiritualitas Kristiani. Umat Kristen terbilang mampu menggunakan hasil perkembangan sains dan teknologi dalam sistem digital. Meskipun pembelajaran, pengawasan dan penguasaan diri sebagai umat Tuhan merupakan hal-hal yang terus-menerus melekat di dalamnya. Majunya dan semakin banyaknya temuan sains dan teknologi dalam berbagai bentuk, membuat umat Kristiani ditantang untuk mempublikasikan diri dan panggilan pemuridannya dalam konteks berteknologi digital dengan berbagai media. Kristen dan teknologi penting menjadi satu pokok bahasan kajian yang bisa dimasukkan ke dalam payung keilmuan besar teologi dan sains yang selama kurang diperhatikan dalam denominasi tertentu. Kristen dan teknologi sebagai satu diskursus akademik di dalam kelas-kelas perkuliahan akan menjadi sangat aplikatif dalam kehidupan luas mahasiswa dan masyarakat Kristiani di kemudian hari apalagi dengan menyertakan sisi etika, literasi, dan ciptaan sebagai sub-sub bahasan di dalamnya. Pembahasan ini menjadi amat penting di zaman teknologi agar pemahaman dan perilaku bagaimana seharusnya umat Kristiani menempatkan dirinya di tengah-tengah tantangan baru di zaman baru yang nyata sekarang ini menjadi terkelola dengan dewasa.
\end{abstract}

Kata kunci: Kristen, teknologi, etika, literasi, penciptaan

\begin{abstract}
With ethical awareness, literacy abilities, and awareness as God's intelligent creatures, Christians in various dynamics of life must continue to show a human ethics and spirituality, especially in the context of Christian ethics and spirituality. The Christians are able to use the results of the development of science and technology in digital systems. Although, learning, supervision and self-control as God's people are things that are constantly attached to it. With the advance and increasing number of scientific and technological discoveries in various forms, Christians are challenged to publicize themselves and their discipleship calls in the context of digital technology with various media. Christianity and technology become important topics of study that can be included in the umbrella of the great scientific knowledge of theology and science which have been under-attention in certain denominations. Christianity and technology as an academic discourse in lecture classes will be very applicable in the broad life of students and the Christian community in the future, especially by including the ethics, literacy, and creation as sub-topics in it. This discussion has become very important in the age of technology so that understanding and behavior of how Christians should place themselves in the midst of new challenges in the real new age is now being managed with adulthood.
\end{abstract}

Keywords: Christians, Technology, Ethics, Literacy, Creation 


\section{Pendahuluan}

Teologi dan sains adalah dua bidang besar dalam peradaban manusia. Kajian ini akan menjelaskan teologi dan sains tempat manusia, secara khusus umat Kristen yang merupakan subjek pengguna di dalamnya. Dalam Surat Apostoliknya mengenai "Perkembangan Cepat” yang terangkum dalam Seri Dokumen Gereja No. 111, Paus Yohanes Paulus II mengatakan bahwa ilmu pengetahuan dan teknologi adalah hasil yang indah dari kreativitas manusia, yang diberikan Allah. Itu artinya sebagai umat Kristiani tidak didorong untuk tidak antipati terhadap teknologi namun bagaimana menggunakan teknologi tersebut dengan bijak sehingga dapat memuliakan nama Tuhan melalui seluruh perkembangan dan kreasi-kreasi teknologi yang ada. Tuhan menciptakan teknologi dengan kebijaksanaan-Nya demi kebaikan semua sehingga setiap orang, secara khusus umat Kristiani mesti menggunakannya dengan bijaksana pula (bdk. Mazmur 104:24 “Betapa banyak perbuatan-Mu, ya Tuhan, sekaliannya Kaujadikan dengan kebijaksanaan, bumi penuh dengan ciptaan-Mu").

Namun sebagaimana diketahui bahwa perkembangan teknologi memang seperti dua sisi mata uang. Di satu sisi bisa menimbulkan efek positif dan di sisi lain bisa menimbulkan efek negatif jika tidak digunakan secara benar. Karena itu penting untuk disertakan sebuah etika dan spiritualitas manusia, terutama dalam konteks ini, etika dan spiritualitas Kristiani dalam menggunakan hasil perkembangan sains dan teknologi dalam sistem internetisasi. Bahwa salah satu bentuk dari kemajuan zaman dan peradaban manusia dalam berteknik (techne) yang sangat nyata seperti internet, media transportasi, revolusi produksi yang dengan segala kemampuannya mampu memudahkan aktivitas kehidupan manusia sekaligus dalam kemajuannya membawa implikasi negatif bagi umat manusia. Hasil teknologi memang memberikan kegembiraan dan harapan yang begitu besar bagi banyak orang saat ini, namun sekaligus membawa duka dan kecemasan yang sangat nyata. ${ }^{171}$

Dengan demikian, dengan kemajuan dan penemuan sains dan teknologi dalam berbagai bentuk, umat Kristen diajak untuk mendalami disposisi diri dan panggilan pemuridannya dalam konteks berteknologi. Atau dengan kalimat lain, bagaimana seharusnya umat Kristen menempatkan dirinya di tengah-tengah tantangan baru di zaman baru yang nyata sekarang ini, yakni "zaman teknologi”?

\footnotetext{
${ }^{171}$ Paus Yohanes Paulus II, Gereja dan Internet, Etika dalam Internet, Perkembangan Cepat, RP. F.X Adisusanto, SJ (terj). (Jakarta: Departemen Dokumentasi dan Penerangan KWI, 2019), 4.
} 


\section{Teologi dan Sains}

Untuk lebih mendalam memahami teologi tidak cukup sampai hanya pada makna etimologinya, ilmu (logia) tentang Allah (Theos), melainkan pada hakikat teologi itu sendiri yang dirumuskan dalam sebuah definisi atau batasan. Maka definisi teologi adalah pengetahuan adikodrati yang metodis, sistematis, koheren tentang apa yang diimani sebagai wahyu Allah atau berkaitan dengan wahyu itu. ${ }^{172}$ Azas pengetahuan teologi tidaklah terbatas pada pengalaman inderawi dan logika seperti ilmu empiris lainnya. Teologi bersifat adikodrati (melebihi daya kodrat insani) yang didasarkan wahyu Allah yang diterima manusia dalam iman. ${ }^{173}$ Karena itu teologi Kristiani adalah refleksi ilmiah orang Kristen atas iman yang mereka hayati sebagai orang Kristiani. Ini terutama berkaitan dengan wahyu Allah yakni bahwa Allah telah memasuki sejarah umat manusia secara istimewa yakni dalam pewahyuan diri-Nya, mulai dari panggilan Abraham dan memuncak dalam peristiwa Yesus ${ }^{174}$. Di dalam wahyu itu Allah sendiri menyapa manusia, memperkenalkan diri-Nya dan mengajak manusia ikut serta dalam kehidupan Allah sendiri. ${ }^{175}$ Tanggapan manusia yang diharapkan oleh Allah sebagai jawaban atas wahyuNya ialah iman. ${ }^{176}$ Tanggapan yang dimaksud dalam iman adalah ikut serta dalam karya penciptaan Allah di dunia. Karena itu, manusia disebut co-creator Allah di dunia.

Sementara itu, sains adalah kumpulan pengetahuan, proses, kumpulan nilai dan cara untuk mengenal dunia. ${ }^{177}$ Sebagai kumpulan nilai, Hardy dan Fleer (1996) menekankan aspek nilai ilmiah dalam sains yaitu nilai kejujuran, rasa ingin tahu, dan keterbukaan saat dan setelah seseorang melakukan proses-proses sains. ${ }^{178}$

Teologi dan sains memperlihatkan beberapa prinsip dasar. Teologi berada di wilayah kedirian personal dan sains di wilayah objek-objek impersonal. Teologi berurusan dengan tatanan dunia dan kehidupan batin manusia sementara sains menyoal data yang bersifat publik, objektif dan dapat diulang. Dasar otoritas teologi (agama) adalah Tuhan, wahyu dan pengalaman pribadi sedangkan sains adalah koherensi logis

\footnotetext{
172 Nico Syukur Dister, Pengantar Teologi (Yogyakarta: Kanisius, 1991), 17.

173 Ibid., 18.

174 Ibid.

175 Nico Syukur Dister, Pengantar Teologi, 85.

176 Ibid.

${ }^{177}$ Hardy.T \& Fleer. M., Science for Children: Developing a Personal Approach to Teaching (Sydney: Prentice Hall. Paul Chapman. Publishing Ltd, 1996)

178 Ibid.
} 
dan ketepatan eksperimental. ${ }^{179}$ Dualisme konsep ini kemudian membuat kedua bidang besar ini seakan tidak saling bertemu. Namun jika ditelaah secara lebih saksama maka akan kelihatan sebuah hubungan "dialogis" yang tidak langsung antara keduanya. Konteks "dialogis" yang dipetakan di sini adalah salah satu dari empat tipe hubungan antara sains dan agama menurut Ian Barbour.

Situasi abad XX menjadi pemicu kesadaran hubungan ini. Para ilmuwan mulai menyadari bahwa di puncak perkembangannya sains terpaksa bertemu pula dengan pertanyaaan-pertanyaan religius. Keteraturan, rasionalitas dan inteligibilitas alam tetaplah misterius dan menyudutkan ilmuwan seperti Einstein pada kekaguman spiritual. Wolfhart Pannenberg melihat kemungkinan dialogis lebih eksplisit: pada satu titik sains akan berhadapan dengan pertanyaan-pertanyaan tentang masa depan yang tidak akan pernah terprediksi sepenuhnya, pada titik itulah teologi dapat berperan sebab teologi adalah studi tentang realitas sebagai keseluruhan. Karl Rahner melihat kiprah alam semesta -termasuk proses evolusinya- sebagai ekspresi kreatif dan komunikasi diri Tuhan melalui penyebab-penyebab alamiah. Wahyu (Kristiani) adalah klimaks proses tersebut. Sementara David Tracy menyoroti "situasi batas" yakni ketika sains harus mempertimbangkan masalah-masalah etis yang ditimbulkannya, juga saat ia mempertanyakan asumsi-asumsi dasar dan syarat yang memungkinkan sains itu sendiri. ${ }^{180}$

Pada akhir abad XX, salah satu penemuan mutakhir dalam kosmologi adalah "The Anthropic Principle" yang menyatakan bahwa seluruh proses alami rupanya telah disetel dengan sedemikian tepat (fine-tuned) sehingga memungkinkan munculnya kehidupan. Freeman Dyson kemudian melihat arsitektur semesta konsisten dengan hipotesis bahwa suatu akal budi berperan dalam keseluruhan proses itu. Hipotesis tersebut sering disejajarkan dengan argumen "desain" dalam kosmologi yang kerap dipakai dalam teologi juga. ${ }^{181}$

Maka dalam konteks dialogis inilah teologi (agama) dan sains harus saling terbuka. Sains membuka diri terhadap kearifan dan kedalaman teologi (agama) dan teologi tidak hanya bernostalgia. Saling terbuka ini berarti mengubah cara berpikir, yakni

\footnotetext{
${ }^{179}$ Lih., Bambang Sugiharto, “Agama dan Sains” dalam Bartolomeus Samho, dkk (Peny.) Agama dan Kesadaran Komtemporer (Yogyakarta: Kanisius, 2009), 143.

180 Ibid., 144.

${ }^{181}$ Lih., Bambang Sugiharto, "Agama dan Sains" dalam Bartolomeus Samho, dkk (Peny.) Agama dan Kesadaran Komtemporer 145.
} 
dalam konteks ini memahami Tuhan dan cara kerja, juga tentang asal-usul alam semesta ini. Sebagaimana kata Thomas Aquinas, Tuhan adalah penyebab primer tetapi bekerja melalui penyebab sekunder yakni yang juga dipelajari sains. ${ }^{182}$ Dalam ungkapan Hartshorne, sifat dan tujuan Tuhan tidak berubah namun pengalaman dan pola hubungan-Nya dengan kita berubah-ubah. ${ }^{183}$ Mengingat kemunculan sains dan teologi sama -sama dibangun dari pengalaman manusia dan keduanya bisa saling memberi kontribusi. Termasuk bagi umat Kristen yang ada sedang ada dalam dunia tempat sains berkembang dengan sangat spektakuler. Konteks berteologi harus dipadupadankan dengan perkembangan sains -maupun sebaliknya- (sebagai bentuk dialogis), karena akar dasar keduanya adalah diciptakan manusia atas izin Allah sendiri. Maka bagi umat Kristen, berteologi yang baik adalah mampu memanfaatkan sains untuk membaca sifat, tujuan dan hubungan dengan-Nya dalam dunia manusia sehingga tidak merusakkan apa yang "telah disetel dengan sedemikian tepat (fine-tuned) sehingga memungkinkan munculnya kehidupan" tadi. Atau sebaliknya, ber-techne yang baik harus diselaraskan dengan apa yang menjadi tujuan Allah di dunia sebagaimana yang diimani dalam iman Kristiani. Melengkapi pembahasan mengenai topik ini, penulis menggunakan analisis kepustakaan guna memperkuat gagasan-gagasan yang disampaikan.

\section{Literasi Teknologi dan Keutuhan Ciptaan}

Sekilas, kata-kata ini terkesan sulit namun sebetulnya adalah hal sederhana. Menurut Maryland Technology Education State Curriculum literasi teknologi ialah kemampuan untuk menggunakan, memahami, mengatur dan menilai suatu inovasi yang melibatkan proses dan ilmu pengetahuan untuk memecahkan masalah dan memperluas kemampuan seseorang. ${ }^{184}$ Dengan kata lain, menuntut pemahaman tentang teknologi pada sebuah tingkatan yang memungkinkan pemanfaatan secara efektif dalam masyarakat teknologi modern yaitu melalui pengetahuan, kemampuan dan berpikir kritis, serta pembuatan keputusan. Menurut Rose, istilah literasi teknologi dapat dimaknai sebagai pemahaman atas hasil karya buatan manusia, hubungan antara sains, lingkungan, dan teknologi. Kemampuan untuk menggunakan teknologi khususnya

\footnotetext{
182 Ibid., 143.

183 Ibid., 146.

${ }^{184}$ Maryland Departement of Education (2005). Maryland Technology Education State Curriculum. Dapat diakses di marylandpublicschools.org
} 
dalam pembelajaran dan pengajaran sains dan kemampuan berinkuiri dan kemampuan untuk mengevaluasi dan membuat suatu keputusan. 185

Berdasarkan kedua definisi di atas, maka literasi teknologi dapat dimaknai sebagai kemampuan yang terdiri dari aspek ilmu pengetahuan, keterampilan berpikir kritis, serta pembuatan keputusan dalam upaya pemanfaatan teknologi atau inovasi hasil karya manusia secara efektif khususnya pada dunia pendidikan.

Sementara itu yang dimaksud dengan keutuhan ciptaan adalah suatu keadaan yang tidak retak, terpisah-pisah, tercerai berai. Sedangkan ciptaan adalah semua makhluk ciptaan Tuhan yakni manusia, alam semesta dan segala isinya. Keutuhan ciptaan mempunyai arti suasana hidup yang diwarnai oleh kesatupaduan, yang menyeluruh dari semua ciptaan Tuhan, hidup bersama di alam semesta sebagai saudara satu sama lain. Yang dimaksud dengan keutuhan ciptaan bukan hanya perihal menjaga lingkungan dan alam saja namun juga membangun relasi persaudaraan universal (karena hakikatnya semua yang ada di bumi berasal dan tertuju pada Sumber yang sama). Ada kesadaran bahwa manusia tidak hidup sendiri dan kesadaran akan sebab akibat perbuatan yang dilakukan sehingga dibutuhkan cara berpikir holistik-integral bukan sebatas membicarakan cara menjaga alam melainkan berpartisipasi dalam dinamika hidup secara keseluruhan dengan lebih harmonis.

Melalui pemahaman tentang literasi teknologi dan keutuhan ciptaan, manusia (umat Kristiani) tertantang untuk mengerti, memahami, memutuskan dan melakukan hal yang mungkin tidak memberikan rasa nyaman pada awalnya. Ini sekaligus menjadi panggilan pemuridan dalam konteks global untuk berani menantang kebiasaan zaman dan partisipasi dalam tugas kenabian Kristus yang telah diemban sejak pembaptisan. Panggilan untuk memperdalam makna hidup dan sekaligus inspirasi mengolah hidup secara baik dan benar sebagai rekan kerja Allah di dunia secara khusus mengolah dan memelihara taman dunia dengan seluruh elemen yang ada di dalamnya. Dalam dimensi partisipatoris ini, manusia, umat Kristiani juga umat beragama lain perlu mengerti dan memahami berbagai macam teknologi bersama literasinya dalam konteks menjaga keutuhan ciptaan sehingga aplikasi pendayagunaan teknologi sebagai anugerah Allah yang bermanfaat bagi kehidupan dapat berjalan secara tepat guna. Dengan prinsip "tepat

\footnotetext{
${ }^{185}$ Rose, Annette Mary, "Perceptions of Technological Literacy among Science, Technology, Engineering, and Mathematics Leaders" Journal of Technology Education. Vol. 19 No. 1, Fall 2007.
} 
guna" ini dapat mencegah model perkembangan yang bagaikan predator dan tidak adil. Kecenderungan menerapkan kecerdasannya untuk hal-hal positif, manusia seringkali, pada saat bersamaan, tidak sungguh-sungguh memperhatikan seluruh bagian dalam satu keterkaitan dan keterikatan yang sering tak tampak secara nyata. Sehingga, tak dipungkiri segala model perkembangan cenderung mengarah pada paradigma mekanistis dan pragmatis yang mengabaikan nilai-nilai intrinsik segala hal yang berada di luar diri manusia. Suatu perkembangan dan pengolahan yang lebih bersifat reduksionis ketimbang yang berkelanjutan. Perkembangan yang berkelanjutan sebagai aspek utama dalam pemanfaatan teknologi beserta literasinya merupakan wujud nyata keikutsertaan menjaga keutuhan ciptaan dan mengurangi pelbagai permasalahan yang ada seperti mengurangi angka kemiskinan, ketidaksediaan air bersih, ketidakadilan ekonomi, politik teknokratis, gizi buruk dan hal-hal lainnya. Manusia harus ingat bahwa, meminjam ungkapan Mahatma Gandhi "bumi menyediakan cukup untuk memenuhi setiap kebutuhan manusia tetapi tidak untuk keserakahan setiap orang."186 Bumi hanya satu dan itu adalah rumah kita bersama.

Bentuk partisipasi dalam cara yang sederhana, berkelanjutan sekaligus bisa dipraktekkan adalah kebiasaan mencuci piring di komunitas Eco Camp yang bernaung di bawah Yayasan Sahabat Lingkungan Hidup ${ }^{187}$ (tempat penulis bekerja). Lazimnya, mama lemon atau sejenisnya (sebagai hasil teknologi) digunakan untuk mencuci dan menghilangkan bekas minyak dan bau amis pada peralatan makan. Namun kebiasaan berbeda justru dilakukan di komunitas ini yakni menggantikannya dengan sabun lerak (biji pohon lerak yang ditumbuk setengah halus lalu direndam dalam air bersih), tidak berbusa apalagi mengandung ekstrak detergent yang bisa meracuni tanah (bumi). ${ }^{188}$

\section{Pengetahuan dan Teknologi Sebagai Anugerah Tuhan}

Karena teknologi diciptakan oleh manusia dengan kemampuan yang diberikan oleh Tuhan (dengan kata lain adanya teknologi merupakan kehendak Tuhan) maka tuntutan bagi semua orang khususnya orang Kristiani adalah menggunakan teknologi

\footnotetext{
${ }^{186}$ Satish Kumar, Soil, Soul, Society (A New Trinity for Our Time) (United Kingdom: Leaping Hare Press, 2015), 20.

${ }^{187}$ Yayasan Sahabat Lingkungan Hidup merupakan rumah belajar tentang lingkungan yang di dalamnya dikembangkan aktivitas edukasi, konservasi, riset dan pengembangan komunitas serta berbagai aktivitas kreatif lainnya yang berbasis lingkungan. Sebagai lembaga edukasi, yayasan ini menjangkau semua kalangan, anak-anak, remaja, dewasa dan orang tua. Yayasan ini terletak di Jl. Pakar Barat No. 3 Dago-Bandung.

${ }^{188}$ Catatan editor: kerap disebut sebagai "Green chemistry."
} 
dengan memperhatikan keutuhan ciptaan. Pengetahuan yang diberikan kepada manusia dimaksudkan agar manusia membangun kesadaran dari dalam dirinya tentang kebaikan dan kebijaksanaan Tuhan dalam setiap kreasi dan inovasi dalam hal sains dan teknologi. Dengan kesadaran itu, manusia akan mampu menggunakan segala ilmu pengetahuan dan teknologi terarah pada kemuliaan Tuhan, dengan etika dan tujuan yang baik, membantu orang lain menyadari kebaikan Tuhan dan mengolah bumi dengan penuh tanggung jawab. Ini merupakan panggilan manusia sebagai rekan kerja Allah di dunia terutama umat Kristiani yang sedari awal mengemban tugas-tugas kenabiaan sebagai murid Kristus.

Sudah sedikit disinggung dalam pendahuluan di atas bahwa teknologi adalah anugerah Allah sendiri melalui manusia. Namun sebagai manusia terutama orang beriman pada umumnya dan umat Kristiani pada khususnya, penggunaan teknologi dengan bijaksana bukan hanya semata-mata berpartisipasi dalam menjaga keutuhan ciptaan dari ancaman kehancuran atau sekadar ikut-ikutan melainkan penggunaan teknologi harus merupakan sebuah ungkapan syukur atas anugerah Allah kepada manusia. Kesadaran ini penting mengingat sedari awal melalui kisah penciptaan, Allah secara tak langsung memberi pengetahuan kepada manusia tentang relasi dan eksistensinya dengan dan dalam dunia. Karena itu, manusia juga umat Kristiani, tidak boleh berhenti pada pemahaman teknologi sebagai anugerah-Nya tetapi dalam pengertian yang komprehensif-integral menggunakannya dengan penuh tanggung jawab sebagai bagian integral dari iman. Penggunaan teknologi harus didasarkan pada interpretasi yang tepat atas mandat Allah sehingga harmoni antara Pencipta, manusia dan semua ciptaan tetap terjaga. Kekeliruan atas mandat Allah untuk "menaklukkan" bumi (lihat Kejadian 1:28) akan menciptakan antroposentrisme modern yang berujung pada ketidakadilan, relativisme praktis dan paradigma teknokrasi. Di sini manusia memosisikan dirinya (mengira) "dapat mengambil tempat Allah dan menolak diri sebagai makhluk yang terbatas"189 Manusia mendekati semua ciptaan lain di luar dirinya dengan kerangka subjektivitas seakan-akan ia berhadapan dengan sesuatu yang belum terbentuk yang siap dimanipulasi.

Penting untuk menempatkan aspek integral dalam memahami teknologi sebagai anugerah Allah. Sebab semua ilmu hanyalah merupakan respons manusia terhadap

${ }^{189}$ Paus Fransiskus, Laudato Si, terj. Martin Harun, OFM (Jakarta: Obor, 2016), 49. 
wahyu Allah di dalam alam semesta melalui penggunaan potensi kreativitas sebagai citra Allah. Setelah menciptakan manusia, "Allah melihat segala yang dijadikan-Nya itu sungguh amat baik" (Kejadian 1:31). Manusia, sejak awal penciptaan ditetapkan berada dalam posisi antara Allah dan alam, mewakili Allah "menaklukkan alam" dan membawa seluruh alam menyatakan kemuliaan Allah, Sang Pencipta. "Menaklukkan" alam mesti dibaca dalam dalam tafsir yang benar yakni "mengusahakan dan memeliharanya" (Kejadian 2:15). Tetapi karena kehendak bebas yang diberikan oleh Allah kepada manusia disalah gunakan, berakibat dosa. Dosa kemudian menampilkan dirinya "sebagai daya penghancur dalam perang, dalam berbagai bentuk kekerasan dan pelecehan, dalam pengabaian mereka yang paling rentan dan dalam agresi terhadap alam."190

Teknologi yang dikembangkan kemudian menjadi sarana afirmatif melanggengkan paradigmateknokratis yang berimplikasi pada hilangnya harmoni antara Pencipta dan ciptaan. Itu akhirnya hubungan harmoni itu kini berubah menjadi relasi yang makin konfrontatif, ditambah dengan pengakuan atas pandangan bahwa alam seperti mesin yang terus berproduksi, manusia semakin bernafsu memeras segala hal yang mungkin untuk kepentingannya dengan dalih kesejahteraan ekonomi bangsa.

Allah, Sang Pencipta adalah sumber dan inisiator keseluruhan eksistensi. Penciptaan dipahami sebagai refleksi dan emanasi kemuliaan-Nya yang sarat akan nilai dan kebaikan. Penciptaan adalah ungkapan cinta bukan unjuk kekuasaan dan keinginan untuk menegaskan diri. Kasih Allah adalah motif dasar semua ciptaan: "Engkau mengasihi segala yang ada, dan Engkau tidak jijik dengan apapun yang telah Kauciptakan, sebab Engkau tidak akan membentuk apapun yang Engkau benci" (Kebijaksanaan 11:24). Segala yang diciptakan Allah, sangat baik di mata-Nya sehingga sebagai rekan kerja Allah, manusia tidak berhak memberikan interpretasi, makna dan nilai atas seluruh ciptaan di luar maksud Allah. Pernyataan manusia sebagai makhluk yang paling sempurna hendak menunjukkan martabatnya "bukan hanya sesuatu tetapi seseorang." Karena itu, daya ini harus memampukannya mengenal dan menguasai dirinya serta menjadi landasan untuk masuk dalam persekutuan dengan orang lain. Begitu pun dengan setiap bentuk kreativitasnya dalam kehidupan. Manusia harus mampu mengenal dirinya di hadapan teknologi, membatasi dirinya dalam berteknologi dan menggunakan teknologi sebagai sarana perjumpaan yang dialogis (ada dialog iman dan akal). Manusia harus membaca

${ }^{190}$ Ibid., 50 
konteks penggunaan hasil daya ilmu pengetahuan yang diberikan Allah kepadanya dan iman dalam keberagamaannya dalam hermeneutika yang tepat. Kata Abraham Maslow, "agama dan sains seharusnya tidak perlu bertabrakan dan berkonflik. Keduanya merupakan sarana yang berusaha menciptakan kondisi yang lebih baik, yakni terdapat kebebasan, kebahagiaan dan keselamatan bagi manusia". 191

Umat Kristiani misalnya, harus mengaitkan pengetahuannya dengan hikmathikmat biblis. Bahwa dimensi biblis tidak pernah mengizinkan antroposentrisme yang diktatorial yang tidak peduli terhadap keutuhan ciptaan. Sekaligus dengan pengetahuan yang diberikan Allah, menantang manusia "untuk menemukan jalan-jalan cerdas yang mengarahkan, mengembangkan dan membatasi kekuatan kita"192 dalam menggunakan teknologi agar pemanfaatannya terarah pada Sang Pencipta. Ketimbang menggunakan semprotan pestisida, Eco Camp justru menanami setiap sisi luar kebun sayuran dan tanaman organik dengan berbagai jenis bunga. Selain membuat kebun menjadi indah, aneka tanaman bunga tersebut menjadi penangkal bagi hama. Setidaknya, praktek sederhana, salah satu sistem permakultur ini, bisa mengusir hama tanpa harus membunuh sebagaimana lazimnya dengan pestisida.

Kahlil Gibran turut menegaskan perihal pengetahuan dengan berujar, "bila pengetahuan yang kau miliki tak pernah mengajarkan arti sebuah nilai sesuatu dan membebaskanmu dari belenggu materi, niscaya engkau tak pernah mampu menggapai singgasana Kebenaran."193Itu artinya pengetahuan yang ada dalam setiap pribadi harus menemukan konkritisasinya dalam praksis hidup di dunia seturut kehendak Allah.

Tuhan bersukacita dalam segala karya-Nya (Mazmur 104:31). Hikmat ini harus menjangkau dan menjadi inspirasi relasi yang harmonis ketika manusia mengaplikasikan teknologi yang ditemukan dengan lebih efisien dan efektif.Efisien dan efektif boleh dipahami dalam dimensi, bahwa "teknologi ini bisa menjadi sarana untuk memecahkan masalah-masalah kemanusiaan, dengan meningkatkan pengembangan manusia seutuhnya, menciptakan dunia yang dikuasai oleh keadilan, kedamaian dan kasih. Seperti, lebih dari tiga puluh tahun yang lalu, dinyatakan oleh Instruksi Pastoral tentang Sarana-sarana Komunikasi Sosial Communio et progressio, sarana yang tersebut di atas memiliki kemampuan untuk menjamin bahwa setiap orang dimanapun di muka bumi

\footnotetext{
${ }^{191}$ Abraham H. Maslow, Motivation and Personality (USA: Harper and Row Publisher Inc, 1987), 174.

${ }^{192}$ Paus Fransiskus, Laudato Si, terj. Martin Harun, OFM, 59.

${ }^{193}$ Kahlil Gibran, Gairah Asmara, edit. Imam Wahyudi(Jogjakarta: Diva Press, 2004), 90.
} 
"berpartisipasi dalam masalah-masalah berat dan kesulitan-kesulitan yang dihadapi oleh setiap orang dan seluruh masyarakat."194

Dengan demikian, dalam konteks penggunaan teknologi demi keutuhan ciptaan, setiap orang (umat Kristiani) bisa menimba dari inspirasi iman dan penghayatannya melalui doa, puasa dan pantang dan amal. Ketiga hal ini, menjadi spiritualitas sekaligus etika religius, membantu manusia merefleksikan secara kritis eksistensinya sebagai makhluk alam, sosial dan religius. Sebagai sarana refleksi praksis menempatkan dirinya di tengah ciptaan yang lain.

Doa. Dalam konteks menjaga keutuhan ciptaan, doa mesti menjadi landasan dan sumber keputusan penggunaan teknologi bagi semua orang beriman terutama umat Kristiani demi mengendalikan sikap oportunis (kerakusan) sehingga terhindar dari habitus menjadikan teknologi sebagai tujuan bukan sarana. Doa akan membantu mengarahkan manusia pada pengetahuan yang baik dan benar tentang maksud, tujuan, cara kerja dan pemeliharaan teknologi sehingga tidak menjadi boomerang yang membahayakan manusia. doa Karena itu dalam berdoa, tidak boleh seperti orang munafik artinya doa hendaknya menjadi relasi personal dengan Allah.

Puasa dan pantang. Pada zaman sekarang, terdapat berbagai macam model puasa dan pantang dalam konteks menjaga keutuhan ciptaan. Misalnya, puasa menggunakan mobil setiap hari sebagai upaya partisipasi mengurangi polusi udara, puasa menghidupkan AC secara berlebihan sebagai bentuk keikutsertaan mengurangi lapisan ozon yang menyebabkan pemanasan global, puasa menggunakan gadget, pantang air (mengurangi penggunaan air yang tidak perlu), pantang plastik dan berbagai opsi lainnya. Tentu dilakukan dengan sukacita sebagai bentuk solidaritas yang integral menjaga bumi dan menyelamatkan banyak orang. Puasa dan pantang mesti dilakukan dengan tulus hati tanpa banyak mengeluh.

Amal. Beramal yang baik adalah menghindari sikap pamer, mendapatkan pujian dan balasan melainkan untuk membantu orang lain mengarahkan dirinya pada kebaikan Tuhan. Melakukan amal dengan diam-diam seperti kata Matius 6:3 "Tetapi jika engkau memberi sedekah, janganlah diketahui tangan kirimu apa yang diperbuat tangan kananmu." Hendaklah sedekahmu itu diberikan dengan tersembunyi. Contoh amal yang bisa dilakukan di era modern ini misalnya, menyisihkan setengah dari biaya bensin mobil

${ }^{194}$ Paus Fransiskus, Laudato Si, terj. Martin Harun, OFM, 33. 
(misalnya sebulan Rp. 400.000) untuk membantu sesama dengan syarat mengurangi pemakaian mobil.

\section{Realita Penggunaan Teknologi Sekarang}

Dengan agak ekstrim Martin Heidegger berkata, teknik yang diciptakan manusia untuk menguasai dunia sekarang mulai menguasai manusia sendiri. ${ }^{195}$ Begitu juga, terjadi konfrontasi antara rumusan konseptual dan data faktual Maslow di atas. Bahwa "agama dan sains seharusnya tidak perlu bertabrakan dan berkonflik" nyatanya tidak demikian.

Ungkapan Heidegger dan ironi konseptual Maslow tidak berlebihan jika dikaitkan dengan realitas kultur kontemporer manusia, misalnya penemuan teknologi tanpa pertimbangan nilai ekologis, kuantitas dan kualitas senjata pemusnah massal yang mengesampingkan nilai intrinsik kehidupan, krisis moral akibat hilangnya refleksi kritis dalam penggunaan media teknologi, dan berkembangnya manipulasi genetis. Elemen penting dari majunya teknologi dalam hal teknologi informasi dan komunikasi sebagai sarana penyebar berita pada dasarnya merupakan penerapan sekaligus perluasan prinsip interkonektivitas, interaksi, dan partisipatoris yang memperlihatkan manusia sebagai makhluk sosial (bdk, Kejadian 1: 27-28). Manusia diciptakan sebagai makhluk sosial yang bertumbuh, berkembang, dan dewasa dalam hubungannya dengan sesamanya. Penciptaan telah menunjukkan sifat partisipatoris dan itu berlangsung dalam hubungan dengan Allah dan dengan sesama manusia.

Dampak majunya sains dan teknologi (teknologi informasi) tak jarang membuat orang menyebut zaman ini sebagai era digital. Berbagai media sosial seperti Facebook, Twitter, Instagram, WhatsApp, Line, Twoo, dirancang dengan konsep interkonektivitas dan jejaring yang menyediakan ruang interaksi atau partisipasi setiap orang. Individuindividu dari berbagai belahan dunia dipertautkan melalui sistem internetisasi. Di sini, meminjam istilah Marshall McLuhan, dunia menjadi semacam kampung global (global village). Semua orang dari berbagai penjuru dunia, yang sebelumnya tak saling kenal, kini bisa saling menyapa hingga membentuk komunitas-komunitas baru dengan berbagai macam tujuan di dalamnya.

"Melalui internet, semua orang dari negara manapun akan saling terhubung. Di sinilah komunitas virtual biasa terbentuk. Komunitas virtual adalah sekelompok manusia dalam dunia maya (cyberspace) yang mempunyai minat yang sama. Dengan adanya kesamaan

195 Kees Bertens, Etika (Jakarta: Gramedia, 1977), 289. 
minat maka seseorang akan bergabung dengan komunitas-komunitas online yang disukai." 196

Peluberan informasi sebagai akibat dari semakin digdayanya teknologi informasi menghatam orang seperti tsunami sehingga kadang kala orang tidak memiliki pegangan kuat (sehingga yang dipilih adalah keyakinan simplistik dan instan) untuk memilah informasi yang bergerak di ruang publik. Orang kehilangan kedalaman, dan tak jarang melahirkan generasi baru pengguna internet yang, oleh Nicholas Carr, disebut sebagai "Orang-orang Dangkal" (The Shallows) yang sering menyantap informasi atau berita instan dan tanpa kedalaman yakni melalui refleksi kritis. Apalagi dengan lompatan langsung dari tahap tradisional ke tahap elektronis, budaya audio-visual menjadikan masyarakat cenderung pasif dan konsumtif terhadap informasi, dan kurang mempunyai kemampuan serta kesempatan untuk mengolah informasi secara kritis. Dengan demikian bisa dimengerti betapa mudahnya massa menjadi sasaran manipulasi. ${ }^{197}$

Dengan kemajuan teknologi semua mobilitas manusia dan aktivitas rumah tangga menjadi lebih mudah. Perpustakaan, pendidikan, konsultasi, transaksi bisnis, bank dan ekonomi, kini dapat berlangsung secara daring (online). ${ }^{198}$ Yang paling nyata adalah harihari ini, apalagi di tengah pandemi Covid-19, hampir semua orang, di semua bidang kehidupan merasakan dampak positif dari teknologi. Kegiatan belajar mengajar, perkuliahan, perkantoran bisa dilakukan secara online bahkan belanja serta pertemuan antara para pejabat negara, dan semua aktivitas tersebut bisa dilakukan dari rumah.

Namun terlepas dari segala hal positif yang ditawarkan oleh kemajuan teknologi, tidak dapat dipungkiri bahwa teknologi pun kerap menyisakan berbagai macam sisi ironisnya. Spiritualitas dan keimanan dunia postmodern cenderung "berada dalam ancaman dekonstruksi, peragu-raguan, baik oleh pemikiran sekuler, rasionalistik dan materialistik, maupun keragaman pemikiran keagamaan."199 Di sini, Tuhan yang dalam ajaran agama-agama, seharusnya menjadi oase dan acuan nilai moral "mengalami kematian" dalam diri manusia. Oleh karena Yang Ilahi kehilangan tempat dalam dirinya, manusia merasa tidak terikat kewajiban moral untuk mencari kebenaran sebagaimana

\footnotetext{
${ }^{196}$ Shiefti Dyah Alyusi, Media Sosial: Interaksi, Identitas dan Modal Sosial (Jakarta: Kencana, 2016), 38. ${ }^{197}$ Dr. C. Putranto SJ, Agama Menghadapi Zaman (Iman Katolik Menghadapi Tantangan Zaman), (Jakarta: Asosiasi Perguruan Tinggi Katolik, 1992), 132.

${ }^{198}$ Lihat, "Warga Gereja Merespon Revolusi Media Sosial” (Jakarta: PGI, 2018), iii.

${ }^{199}$ Haidar Bagir, Islam Tuhan, Islam Manusia: Agama dan Spiritualitas di Zaman Kacau, 43
} 
kodrat asalnya. Albert Einstein berkata, "ilmu pengetahuan akan agama akan lumpuh, dan agama tanpa ilmu pengetahuan akan buta". Agama akan menjadi perisai daya tahan nilai dan moral dalam mengembangkan dan memanfaatkan teknologi. Sementara dengan teknologi, keberagmaan (cara hidup) akan makin terbuka terhadap kemampuan akal memahami teks, konteks, pewahyuan menuju kematangan spiritual.

Dengan demikian, dapat dilihat bahwa realita penggunaan teknologi sekarang ini bisa berdampak positif dan negatif. Dampak positif sudah disebut yakni aktivitas keseharian masyarakat di tengah pandemi dilakukan secara online. Sementara negatifnya, banyak orang melalui internet justru menyebarkan konten-konten yang tidak manusiawi seperti yang dilakukan Youtuber, Ferdian Paleka di Bandung dengan kreasi konten prank sembako sampah.

Sebagai manusia (umat Kristiani) sekaligus pengguna teknologi boleh memperkirakan posisi diri dan hal yang perlu direkonstruksi kembali dalam berteknologi. Kembali kepada hikmat Alkitabiah merupakan akses menuju spiritualitas teknologi dalam kerangka menjadi co-creator Allah di dunia. Spiritualitas berteknologi tidak lain adalah memiliki kesadaran humanis dan ekologis.Umat Kristiani, yang secara khusus menjadi prioritas sudut pandang diskursus ini, boleh menggali terang refleksi kateketis, misalnya dari Keluaran 35:30-35,

"Berkatalah Musa kepada orang Israel: "Lihatlah, Tuhan telah menunjuk Bezaleel bin Uri bin Hur, dari suku Yehuda, dan telah memenuhinya dengan Roh Allah, dengan keahlian, pengertian dan pengetahuan, dalam segala macam pekerjaan, yakni untuk membuat berbagai rancangan supaya dikerjakan dari emas, perak dan tembaga; untuk mengasah batu permata supaya ditatah; untuk mengukir kayu dan untuk bekerja dalam segala macam pekerjaan yang dirancang itu. Dan Tuhan menanam dalam hatinya, dan dalam hati Aholiab bin Ahisamakh dari suku Dan, kepandaian untuk mengajar. Ia telah memenuhi mereka dengan keahlian, untuk membuat segala macam pekerjaan seorang tukang, pekerjaan seorang ahli, pekerjaan seorang yang membuat tenunan yang berwarna-warna dari kain ungu tua, kain ungu muda, kain kirmizi dan lenan halus, dan pekerjaan seorang tukang tenun, yakni sebagai pelaksana segala macam pekerjaan dan perancang segala sesuatu."

Narasi biblis di atas menampilkan dua tokoh yaitu Bezaleel bin Uri bin Hur dan Aholiab bin Ahisamakh sebagai cermin keadaban menggunakan pengetahuan (untuk menghasilkan teknologi) yang terarah pada kemuliaan Tuhan. Pengetahuan yang diberikan oleh Tuhan kepada Bezaleel direalisasikan secara benar dalam rupa tabut perjanjian dari kayu penanga. Sementara bagi Aholiab, menerjemahkan pengetahuan 
yang diberikan oleh Tuhan dalam bentuk alas pintu kemah suci, kain korden kemah suci dan pakaian para imam lengkap dengan segala keindahannya.

Kedua tokoh ini adalah cermin dan peneguh bagi umat Kristiani agar kita dapat memberikan respon atas anugerah Tuhan yang selalu memiliki tujuan yang baik. Perkembangan pengetahuan manusia membuat manusia mampu menemukan teknologi untuk mempermudah proses pengolahan sumber daya alam yang ada. Pemanfaatan kemajuan teknologi menunjukkan panggilan partisipatoris secara bertanggung jawab atas tindakan kreatif Allah. Namun adanya teknologi seringkali menempatkan manusia pada paradigma pengagungan konsep subjek yang dengan prosedur logis dan rasional, mendekati dan mengontrol ciptaan lain secara totaliter bahkan pada titik yang lain, mengira bisa menggantikan posisi Allah. Dan itu yang terjadi dengan peristiwa kejatuhan manusia sebagaimana dilukiskan dalam narasi Taman Eden. Manusia lupa bahwa "takut akan Tuhan adalah permulaan pengetahuan" (bdk. Amsal 1:7).

Fragmentasi pengetahuan manusia pada satu sisi bermanfaat tetapi pada sisi lain kehilangan kepekaan pada hubungan berbagai hal dalam cakrawala yang lebih luas sehingga menjadi tidak relevan. Kata Paus Fransiskus, memang "tidak ada yang menyarankan untuk kembali ke zaman batu, namun sangat penting untuk memperlambat langkah dan melihat realitas dengan cara lain, menyambut baik kemajuan positif dan berkelanjutan dan pada saat yang sama memulihkan kembali nilai-nilai dan tujuan-tujuan yang agung yang hancur karena manusia menganggap dirinya besar tanpa adanya kendali." 200

Dengan demikian, untuk mengembalikan kesadaran menggunakan teknologi dalam konteks melakukan amanat menjaga bumi (keutuhan ciptaan) manusia dituntut untuk segera "pelajarilah kata-kata bijak Sang Arif lalu bumikanlah tempat kamu berpijak. Hidupkanlah kata-kata itu"201 Dan, kata-kata itu ada dalam diri manusia sebagai gambar dan rupa Allah, dalam tradisi, budaya dan kearifan lokal, dalam kebajikankebajikan etis kekayaan agama-agama yakni hikmat cerita-cerita Kitab Suci dan prinsip dan etika global lingkungan hidup.

\footnotetext{
${ }^{200}$ Paus Fransiskus, Laudato $\mathrm{Si}$, terj. Martin Harun, OFM, 88-89.

${ }^{201}$ Kahlil Gibran, Gairah Asmara, edit. Imam Wahyudi, 90.
} 


\section{Aksi Literasi Teknologi}

Pembaharuan hidup dapat dan berlangsung pada setiap elemen masyarakat. Komunitas religius dan semua orang beriman secara khusus umat Kristiani dapat memainkan peran yang sangat penting untuk membangun kesadaran pada gaya hidup yang berkelanjutan. Dengan berlandaskan pada imannya, umat Kristiani dapat menciptakan gaya hidup yang lebih berkelanjutan. Hal tersebut (iman) menyiratkan gaya hidup yang mempertimbangkan relasi yang baik dengan seluruh ciptaan lebih penting ketimbang mengkonsumsi barang-barang. Hal ini berkaitan juga dengan saudara dan saudari dengan siapa kita berinteraksi, dan juga seluruh ciptaan.

Manusia, dengan pengetahuan dan kesadarannya, kadang kala lalai dalam ketidaksadaran pada kebiasaan-kebiasaan yang berpotensi merugikan dan menyengsarakan orang lain. Misalnya kelekatan pada gawai yang mengakibatkan kurang harmonisnya relasi dengan keluarga, timbul rasa tak nyaman bagi banyak orang. Atau beberapa toserba di Kota Bandung (salah satunya toserba Yogya yang terletak di Jl. Pajajaran No. 83) mewajibkan konsumen membawa sendiri tas belanja yang bukan plastik.

Ini mengingatkan manusia untuk mengasah sikap pengendalian dan mawas diri demi keutuhan ciptaan. Manusia dan ciptaan lain diciptakan oleh Allah baik adanya karena itu diciptakan untuk kebaikan. Kemampuan manusia (yang amat baik seturut citra Allah) itu tampak dalam "kreasi dan daya ciptanya" yang mengagumkan untuk membantu mengolah dan memelihara keutuhan ciptaan. Maka teknologi yang merupakan daya kreasi manusia, diciptakan dengan tujuan membantu manusia dalam mengolah dan memelihara keutuhan ciptaan bukan sebaliknya. Teknologi perlu dimaknai sebagai sarana bukan tujuan, bukan Ilah-Ilah baru yang merusak kehidupan secara menyeluruh.

Teknologi mesti mendapat konkretisasi dalam dunia manusia untuk intensi dan atensi yang baik sehingga terarah pada kesejahteraan bumi dan kebahagian kekal suatu ketika. Singkatnya, daya kreasi manusia dalam bentuk teknologi dan segala kecanggihannya harus mampu membuat dunia manusia menjadi lebih surgawi, menjadi seperti situasi taman eden sebelum kedosaan. Maka poin penting dalam aksi literasi teknologi ini adalah teknologi untuk kebaikan, teknologi perlu dimengerti hanya sebagai sarana bukan tujuan akhir dan teknologi tidak boleh merusak melainkan mendukung keutuhan ciptaan. Beberapa aksi (bukan model final tetapi bisa menjadi alternatif) yang ditawarkan misalnya, 


\section{Tahu Saat Berhenti Menggunakan Teknologi}

Kemudahan akses yang diberikan membuat teknologi seringkali dipandang sebagai kekuatan sosial yang dominan sehingga timbul suatu pola ketergantungan yang berkaitan dengan usaha pemenuhan kebutuhan dan tujuan hidup. Berkaitan dengan ketergantungan ini, Neil Postman mengatakan, teknologi menciptakan suatu budaya technopoly dalam masyarakat yaitu pendewaan terhadap teknologi dan seluruh aspek kehidupan berada di bawah kontrolnya. ${ }^{202}$ Ini seakan-akan orang tidak bisa hidup tanpa bantuannya. Padahal tidak semestinya demikian. Teknologi dalam berbagai wujudnya merupakan kreativitas manusia, yang diberikan Allah. Penggunaan yang bijaksana adalah yang efektif dan efisien yaitu harus disadari agar tetap setia sebagai "sarana" dan tidak menjadi seperti Ilah-Ilah baru yang merusak interaksi dengan Tuhan, sesama dan lingkungan. Ada waktu mematikan gawai, mematikan lampu bila tidak dibutuhkan, mematikan alat elektronik bila tidak digunakan.

Praksisnya, tahu batas waktu. Umat Kristiani harus cerdik dan bijaksana agar segala sarana teknologi mengarahkan kepada harta Rohani yang kekal tidak menjadikan majikan yang menyesatkan. "Tahu batas waktu" berarti orang memberi ruang refleksi pada diri untuk memperkaya esensi aspek-aspek multidimensional (kita) sebagai makhluk religius, sosial, dan ekologis. Tahu batas waktu mengingatkan umat Kristiani tentang hari Sabat (hari ke-7), waktu untuk Tuhan. Ada waktu-waktu khusus dari hidup manusia untuk beristirahat dan mengkhususkan untuk berdoa, bersyukur, dan menguduskannya bagi Allah dan keutuhan ciptaan. (bdk. Keluaran 31:13, 17 dan Imamat 25:2-4). Umat paroki Gereja Katedral St. Petrus Bandung senantiasa diwajibkan menonaktifkan handphone sebelum dan selama perayaan Ekaristi. Kebiasaan ini terusmenerus diingatkan melalui pengumuman beberapa menit sebelum memulai perayaan Ekaristi. Maksudnya, umat dibiasakan untuk memberikan (secara khusyuk dan penuh totalitas) waktu khusus kepada Tuhan.

Waktu untuk Tuhan dimaksudkan agar umat Kristiani membuka mata dan mampu melihat hak-hak orang lain. Waktu untuk Tuhan adalah perintah "supaya lembut dan keledaimu tidak bekerja dan supaya anak budakmu perempuan dan orang asing

\footnotetext{
${ }^{202}$ Lih., Joseph Straubhaar, Robert LaRose, and Lucinda Davenport, Media Now: Understanding Media, Culture, and Technology (United States of America: Wadsworth, Cengage Learning, 2010), 50.
} 
melepaskan lelah" (Keluaran 23:12). Perintah ini mendorong untuk selalu memperhatikan sebuah dimensi dan etika perlindungan.

Juga, dalam pengertian lainnya, prinsip batas waktu dapat membantu menjauhi seseorang dari kemungkinan dampak aneka simptom, seperti Internet Addiction Disorder seperti withdrawal symptoms yaitu timbul kecemasan, obsesif terhadap segala hal yang akan terjadi di internet, kadang kala terbawa ke alam mimpi dan bahkan menggerakan jari-jari sekan sedang mengetik. ${ }^{203}$ Dengan demikian, kepekaan pada prinsip batas waktu untuk berhenti sejenak membantu manusia (umat Kristiani) berkembang ke arah yang lebih matang perihal dimensi rohani, sosial dan psikologis.

\section{Intensi dan Atensi yang baik dalam Mencipta Teknologi}

Dalam Roma 8:28 dikatakan "Kita tahu sekarang, bahwa Allah turut bekerja dalam segala sesuatu untuk mendatangkan kebaikan bagi mereka yang mengasihi Dia, yaitu bagi mereka yang terpanggil sesuai dengan rencana Allah." Sangat jelas maknanya. Allah bekerja dalam segala sesuatu untuk mendatangkan kebaikan bagi manusia. Umat Kristiani pun terpanggil dalam kasih Allah mendatangkan kebaikan bagi orang lain dalam segala sesuatu terutama dalam karya ciptaannya yaitu membuat teknologi (kreativitas sederhana misalnya) harus mampu mendukung ciptaan. Orang Kristiani mesti menggunakan teknologi untuk hal-hal baik seperti untuk evangelisasi (re-evangelisasi, evangelisasi baru), kegiatan-kegiatan misioner, dan katekese. Internet yang memiliki kemampuan luar biasa mengatasi jarak dan isolasi dapat digunakan membangun komunitas iman virtual dengan orang-orang yang sama-sama memiliki kehendak baik, saling menyemangati dan membantu satu sama lain menyebarkan kasih dan menjadi sahabat bagi yang lain dalam ruang yang lebih luas. Berkaitan dengan intensi dan atensi ini, Dewan Kepausan Untuk Komunikasi Sosial menegaskan bahwa:

"Pengajaran tentang internet dan teknologi baru mencakup lebih banyak dari pada sekadar mengajarkan hal-hal teknis. Orang-orang muda perlu belajar bagaimana hidup baik dalam dunia maya, tahu bagaimana mengambil keputusan yang tepat seturut kriteria moral yang sehat tentang apa yang mereka temukan di sana, dan menggunakan teknologi baru bagi perkembangan seutuhnya dan kebaikan sesama." 204

\footnotetext{
${ }^{203}$ Lih. Crispin Thurlow, Laura Lengel, and Alice Tomic, Computer Mediated Communication Social Interaction And The Internet (London: Sage Publication, 2004), 151-152.

${ }^{204}$ Ibid., 18.
} 
Yang mau digarisbawahi oleh Dewan Kepausan di atas adalah pentingnya pendidikan tentang internet dan teknologi baru, tidak hanya sebatas mengajarkan atau mentransfer ilmu perihal teknik-teknik pengoperasian sistem media digital melainkan harus mampu membentuk "standar dari selera yang baik dan penilaian moral yang benar sebagai salah satu segi dalam pembentukan suara hati." 205 Artinya, dalam hal ini umat Kristiani diharapkan paham tentang cara berteknologi yang dan benar. Sebab segala hal yang baik secara teknik belum tentu baik secara moral karena itu umat Kristiani didorong untuk memiliki pendidikan dalam hal literasi teknologi agar dapat mengerti makna dan tujuan konteks peristilahan "melek teknologi."Namun tidak sekadar "melek teknologi" melainkan mengajar dan mengembangkan pribadi seseorang agar makin berbudaya dengan dan di hadapan teknologi. Dengan semakin berbudaya, harapan pada intensi dan atensi yang baik dalam berteknologi dapat terealisasi.

\section{Melawan Budaya Sekali-pakai-Buang, mempromosikan memelihara kehidupan.}

Dasarnya adalah Kejadian 2: 15 yang mengatakan "Tuhan Allah mengambil manusia itu dan menempatkannya dalam taman Eden untuk mengusahakan dan memelihara taman itu. Tuhan Allah mengambil manusia itu dan menempatkannya di Taman Eden untuk mengolahnya dan memeliharanya." Sejak penciptaan manusia diberi kemampuan untuk memelihara kelangsungan hidup ciptaan-Nya. Memelihara mesti dipraktekan melalui sikap mau terlibat dalam menjaga keharmonisan keluarga sesuai peran, berkesadaran memelihara makhluk hidup lain (tumbuhan dan hewan), mau memperbaiki dan merawat alat-alat cacat atau rusak dan tidak sekadar membuangnya lalu membeli yang baru, menjual barang-barang bekas atau memberikan kepada orang yang membutuhkan merupakan kreativitas yang murah hati wujud partisipasi dalam daya cipta dan pemeliharaan Sang Pencipta terhadap dunia. Gerak partisipatoris dalam menjadi pelindung ciptaan Allah menjadi komitmen yang sangat penting untuk hidup yang berkeutamaan. Hal itu bukanlah pilihan atau aspek sekunder saja dari pengalaman Kristiani. Dengan kata lain, menghayati panggilan sebagai rekan kerja Allah merupakan komitmen spiritualitas iman dalam praksis. Melawan budaya sekali-pakai-buang mengandaikan sikap yang ugahari, bijaksana dan adil dalam menggunakan sumbersumber alam. Mengaplikasikan misalnya komitmen 3 (4) R (reduce, reuse, recycle-repair)

\footnotetext{
${ }^{205}$ Paus Yohanes Paulus II, Gereja dan Internet, Etika dalam Internet, Perkembangan Cepat, RP. F.X Adisusanto, SJ (terj), 17.
} 
dengan mengurangi penggunaan air dan energi, mengurangi sampah-sampah plastik, styrofoam, kemasan-kemasan plastik dan alumunium, menggunakan sarana-sarana transportasi yang hemat dan ramah lingkungan merupakan promosi budaya memelihara kehidupan secara sederhana namun mendalam. Satu kebiasaan yang masih dirawat di kampung halaman (Maumere-Flores) hingga hari ini adalah kebiasaan mewariskan seragam sekolah (SD, SMP, SMA) kepada adik-adik atau anak tetangga. Penulis mengalaminya semasa duduk dibangku SMA.

Melawan budaya sekali-pakai-buang ini pertama-tama mestinya datang dari penghormatan atas martabat manusia sendiri. Jika tidak ada penerimaan terhadap martabat manusia yang paling luhur (kehidupan) maka penerimaan atas kehidupan yang lain menjadi tidak konkrit, sekadar pemahaman retoris tanpa realisasi. Artinya, komitmen ini harus dimulai dari manusia sendiri sebagai ciptaan paling luhur. Manusia dan ciptaan lain terus berhubungan satu dengan yang lain, dan dunia yang diciptakan seturut model ilahi merupakan jejaring relasi. Semua kehidupan di dunia condong dan terarah kepada Sang Kehidupan sehingga meskipun tidak tampak (terjalin tersembunyi) terjadi relasi konstan yang terus berkesinambungan. Karena relasi itu maka kesetiakawanan global terus mengalir.

\section{Mempromosikan Kebaikan Lewat Teknologi (Saring sebelum sharing)}

Kitab Amsal 12:14a mengingatkan umat Kristiani bahwa "setiap orang dikenyangkan dengan kebaikan oleh karena buah perkataan, dan orang mendapat balasan daripada yang dikerjakan tangannya." Manusia akan semakin merasa baik bila dalam buah perkataannya pun menyebarkan kebaikan. Internalisasi pemanfaatan yang bijaksana atas teknologi informasi akan tampak pada pemahaman yang kohesif tentang fungsi, tujuan dan dampak bermedia. Bahwa orang tidak sedang dalam posisi melawan kemajuan teknologi adalah sebuah kenyataan. Meskipun demikian, dianjurkan agar setiap individu tetap mawas diri agar tidak dikendalikan oleh kemajuan teknologi, dalam hal penggunaan media sosial.

Sebagai citra Allah, manusia terpanggil secara kolektif kepada tugas dan kreativitas yang mendatangkan kebaikan bagi dunia. Dunia adalah kata-kata cinta. Namun akan sulit didengar jika manusia tak henti-hentinya dirasuki oleh kebisingan yang kontinu, kecemasan yang terus mengganggu, euphoria revolusi teknologi yang tidak bermartabat dan atau kultus penampilan. Dan, kesemuanya itu juga merupakan buah atau hasil dari 
kreativitas manusia merespon anugerah Allah dalam ruang dan dimensi yang tercemar oleh paham reduksionis, pragmatis-mekanistis demi mengejar impian-impian yang kurang arif.

Kemampuan untuk memilah informasi sebelum dibagikan dalam bermedia adalah satu bentuk upaya mempromosikan kebaikan lewat teknologi. Aktivitas dan kreativitas melalui media sosial harus dilandaskan pada kebaikan demi kemajuan peradaban (kita) sebagai manusia dan sebagai umat Kristiani. Kebenaran adalah argumen dan prasyarat dari ilmu pengetahuan. Ilmu pengetahuan diberikan Pencipta kepada manusia sebagai daya cipta, rasa dan karsa dan di dalam ketiganya, tergantung unsur moral. Manusia, khususnya umat Kristiani harus mengembangkan daya-daya ini mengingat peningkatan signifikan yang memprihatinkan dalam aktivitas di media sosial dewasa ini. Tendensi manipulatif dalam bermedia adalah simbol hilangnya cinta dan respek terhadap diri dan orang lain. Dan itulah adalah salah satu bentuk dosa. Dostoevsky dalam Novelnya The Brother Karamazov dengan sangat menarik menyingkap relasi antara kebaikan bermedia, relasi dan cinta dengan mengatakan;

"Orang yang berbohong kepada dirinya sendiri dan mendengarkan kebohongannya sendiri berada di jalan yang sedemikian rupa sehingga dia tidak dapat membedakan kebenaran di dalam dirinya, atau di sekitarnya, dan karenanya kehilangan semua rasa hormat untuk dirinya sendiri dan orang lain. Dan tanpa rasa hormat dia berhenti mencintai dan untuk menempatkan dan mengarahkan dirinya tanpa cinta, dia memberi jalan pada nafsu dan kesenangan yang kasar dan tenggelam dalam kebinatangan dalam sifat buruknya, semua dari kebohongan terus-menerus pada orang lain dan pada diri sendiri. Orang yang berbohong pada dirinya sendiri bisa lebih mudah tersinggung dari siapapun"206

Menarik benang merah dari ungkapan Dostoevsky di atas dalam konteks tendensi manipulatif dalam "membagi" informasi melalui teknologi digital adalah, kebohongan dapat membutakan kebenaran dalam hati, membungkam kebenaran faktual realitas, menyebabkan hilangnya respek dan cinta terhadap diri sendiri dan sesama yang akan berujung pada retaknya keutuhan relasi dalam hidup. Mempromosikan kebaikan berarti proaktif dalam upaya saring (berhati-hati dengan judul provokatif, mencermati alamat situs, memeriksa fakta-data, memeriksa keaslian gambar/foto) sebelum aktif membagikannya kepada publik. Karena setiap ujaran yang baik adalah bentuk nyata dukungan antara satu dengan yang lain.

\footnotetext{
${ }^{206}$ Fyodor Dostoyevsky, The Brothers Karamazov, (transl.) Constance Garnett (New York: The Lowell Press, 2009), 48 .
} 


\section{Kesimpulan}

Paparan analisis dalam tulisan ini memperlihatkan daya jangkau di masyarakat Kristiani sekarang. Dalam perkembangannya, teologi dan sains, untuk hal-hal tertentu dilihat dari pengetahuan dan teknologi sebagai anugerah Tuhan, namun dalam realita penggunaan teknologi sekarang, melalui aksi literasi teknologi, intensi dan atensi yang baik dalam mencipta teknologi, perlu kita terus mempromosikan kebaikan lewat teknologi maka ada alasan teoritis dan praksis bahwa Kristen bisa menjadi subjek yang baik atas teknologi.

Dengan kesadaran beretika, kemampuan literasi, dan kesadaran sebagai makhluk ciptaan Tuhan yang smart, maka umat Kristiani dalam kasus-kasus khusus bisa (dan sebaiknya tetap) memperlihatkan sebuah etika dan spiritualitas manusia, terutama dalam konteks etika dan spiritualitas Kristiani. Umat Kristen terbilang mampu menggunakan hasil perkembangan sains dan teknologi dalam sistem digital. Meskipun pembelajaran, pengawasan dan penguasaan diri sebagai umat Tuhan merupakan hal-hal yang terus-menerus melekat di dalamnya. Majunya dan semakin banyaknya temuan sains dan teknologi dalam berbagai bentuk, umat Kristiani ditantang untuk mempublikasikan diri dan panggilan pemuridannya dalam konteks berteknologi digital dengan berbagai media.

Kristen dan teknologi penting menjadi satu pokok bahasan kajian yang bisa dimasukkan ke dalam payung keilmuan besar teologi dan sains yang selama ini tidak banyak dibahas di lingkungan kampus Evangelikal terutama di kelompok-kelompok Pentakosta maupun kharismatik. Kristen dan teknologi sebagai satu diskursus akademik di dalam kelas-kelas perkuliahan akan menjadi sangat aplikatif dalam kehidupan luas mahasiswa dan masyarakat Kristiani di kemudian hari apalagi dengan menyertakan sisi etika, literasi, dan ciptaan sebagai sub-sub bahasan di dalamnya. Pembahasan tersebut menjadi amat penting di zaman teknologi agar pemahaman dan perilaku bagaimana seharusnya umat Kristiani menempatkan dirinya di tengah-tengah tantangan baru di zaman baru yang nyata sekarang ini menjadi terkelola dengan dewasa.

\section{Tentang penulis:}

Lahir di Maumere, Flores pada 20 Maret 1987. Menyelesaikan pendidikan dasar dan menengah di Maumere, Flores. Pada Tahun 2010-2014 menempuh pendidikan di Universitas Katolik Parahyangan, Bandung dan mendapat gelar Sarjana Filsafat (S.S.). Pada Tahun 2014-2016 
melanjutkan pendidikan S2 pada program Ilmu Teologi di universitas yang sama dan meraih gelar Magister Humaniora (M.Hum.). Sekarang melayani di Yayasan Sahabat Lingkungan Hidup, Bandung sekaligus Pemerhati Lingkungan Hidup dan Penulis Lepas. 